\title{
Mean Platelet Volume as a Predictor of Atherosclerotic Severity in Non- ST Elevation Acute Myocardial Infarction
}

\author{
Yuli Astuti*, Budi Yuli Setianto, Nahar Taufiq \\ Department of Cardiology and Vascular Medicine, Faculty of Medicine, Public Health and Nursing Universitas Gadjah Mada \\ - Dr. Sardjito Hospital, Yogyakarta, Indonesia \\ ${ }^{*}$ Corresponding author: \\ Yuli Astuti MD.- email: yastuti7169@gmail.com \\ Address: Department of Cardiology and Vascular Medicine, Faculty of Medicine, Public Health and Nursing Universitas \\ Gadjah Mada, Jalan Farmako Sekip Utara Yogyakarta 55281, Indonesia
}

Manuscript submitted: August 15, 2018; Revised and accepted: November 29, 2018

\begin{abstract}
Background: Acute myocardial infarction (AMI) is the leading cause of death in the world. AMI is classified into ST-elevation myocardial infarction (STEMI) and Non-ST elevation myocardial infarction (NSTEMI). Diagnosis and prediction of severity of atherosclerotic in NSTEMI is a challenge. Despite the risk stratification, $14-20 \%$ of patients that undergo coronary angiography have normal or non significant coronary artery disease. The role of platelet and the extent of atherotrombosis in patients with NSTEMI are interesting field of research. Mean platelet volume (MPV) reflects platelet size and reactivity. It can be used as a diagnostic marker and may have predictive value. This study aims to prove the role of MPV as a predictor of the degree of atherosclerotic based on Syntax score in patients with NSTEMI undergoing coronary angiography.

Methods: This is a cross sectional study enrolled 86 subjects with NSTEMI. Blood samples were taken at the time of admission to the hospital. An MPV was measured by automated machine. Subsequent coronary angiography was performed using standardized method. Syntax score was determined to reflect the atherosclerotic severity. Statistical analysis was used to assess whether an MPV as a predictor of atherosclerotic severity based on Syntax score.

Results: The chi-square analysis showed that high MPV could not be used as a predictor of the atherosclerotic severity based on Syntax score in NSTEMI patients ( $p$ value $=0.5$, prevalence ratio $1.15(95 \% \mathrm{Cl}: 0.755-1.753)$. From multivariate analysis, only smoking factor had an independent relationship with Syntax score $(p$ value $=0.047$; Odds ratio 2.531(95\% Cl: 1.012-6.328).

Conclusions: High MPV cannot be used as a predictor of atherosclerotic severity based on Syntax score in NSTEMI patients.
\end{abstract}

Keywords: NSTEMI; mean platelet volume; atherosclerosis; Syntax Score 


\section{INTISARI}

Latar Belakang: Infark miokard akut (IMA) merupakan penyebab kematian di dunia. IMA diklasifikasikan menjadi ST elevasi (IMA-EST) dan Non ST elevasi (IMA-NEST). Diagnosis dan prediksi beratnya aterosklerosis pada IMA-NEST dan angina pectoris tidak stabil, merupakan tantangan. Meskipun sudah dilakukan stratifikasi risiko, 14-20\% pasien yang dilakukan angiografi koroner didapatkan normal atau non signifikan. Pengenalan peran platelet dan luasnya aterotrombosis pada pasien IMA-NEST menarik untuk dilakukan penelitian. Mean Platelet Volume (MPV) mencerminkan ukuran platelet dan reaktivitas, bisa dipakai sebagai diagnostik dan mungkin mempunyai nilai prediktif. Penelitian ini bertujuan untuk membuktikan peranan MPV yang meningkat bisa sebagai prediktor terhadap derajat beratnya aterosklerosis berdasarkan skor Syntax pada pasien IMANEST yang dilakukan angiografi koroner.

Metode Penelitian: Penelitian ini menggunakan desain penelitian potong lintang sebanyak 86 pasien yang memenuhi kriteria inklusi. Sampel darah diambil pada saat pasien masuk ke rumah sakit. MPV diperiksa dengan mesin otomatis. Angiografi koroner dilakukan dengan metode standar. Skor Syntax dinilai untuk menentukan keparahan lesi aterosklerosis koroner. Analisa statistik digunakan untuk membuktikan rasio prevalensi MPV yang tinggi sebagai prediktor derajad beratnya aterosklerosis berdasarkan skor Syntax.

Hasil: Analisis Chi-Square menunjukkan bahwa MPV yang tinggi tidak bisa dijadikan sebagai prediktor beratnya derajat aterosklerosis berdasarkan skor Syntax pada pasien IMA-NEST yang dilakukan angiografi koroner (nilai $p=0.5$; rasio prevalensi 1.15 dengan IK 95\%: 0.755-1.753. Analisis multivariat diketahui merokok mempunyai hasil yang signifikan dengan $p=0,047$; rasio odds $=2,531$ dan $95 \% \mathrm{IK}: 1,012-6,328$.

Kesimpulan: MPV yang tinggi tidak bisa dijadikan sebagai prediktor beratnya derajat aterosklerosis berdasarkan skor Syntax pada pasien IMA-NEST.

\section{INTRODUCTION}

Acute myocardial infarction is a cause of death in the world. Acute myocardial infarction is classified as ST elevation myocardial infarction (STEMI) and Non ST elevation myocardial infarction (NSTEMI). Clinical symptoms, laboratory cardiac markers, electrocardiography and the presence of risk factors for heart disease can be used to diagnose NSTEMI. Diagnosis and prediction of the severity of atherosclerosis in NSTEMI and unstable angina pectoris, is a challenge. NSTEMI management can be either conservative or invasive. In NSTEMI, high risk stratification is recommended for invasive strategies. ${ }^{1,2}$

Despite risk stratification, $14-20 \%$ of patients who have coronary angiography have normal or non-significant coronary heart disease (CHD). Investigation of new markers combined with cardiac imaging and stress tests may be better for predicting patients with NSTEMI with significant atherosclerosis and may reduce invasive strategies that are not needed. The introduction of the role of platelets and the extent of atherothrombosis in NSTEMI patients is interesting to do research. Mean platelet volume (MPV) reflects platelet size and reactivity, can be used as a diagnostic and may have a predictive value. ${ }^{1,2}$

\section{METHODS}

This study was an observational analytic research using a cross sectional study design. The place of research was 
conducted at the RSUP Dr. Sardjito, Yogyakarta, Indonesia. The subjects of research were patients with a diagnosis of NSTEMI, who were treated in the Intensive Cardiology Care Unit (ICCU) and had been performed a coronary angiography. The time of enrollment was between March 2016 and May 2018.

This study aims to prove the role of increasing MPV as a predictor of the severity of the atherosclerotic degree based on the Syntax score in NSTEMI patients. The subjects of the study were patients who admitted to the Emergency Unit (ER) and were treated at the ICCU of RSUP Dr. Sardjito with a diagnosis of NSTEMI. The demographic and laboratory data were collected through medical records. Laboratory result from peripheral blood when the patient admitted to the ER was retrieved from medical records. The subjects inclusion criteria: (1) patients aged $\geq 40$ years old who came to the ER with complaints of anginal pain that were typical or atypical with ECG recordings showed no persistent ST segment elevation in the two adjacent leads, ST segment depression, inversion of $\mathrm{T}$ waves, and/or flat $\mathrm{T}$ waves, and accompanied by an increased in cardiac enzymes, and (2) patients underwent coronary angiography and percutaneous coronary intervention $(\mathrm{PCl})$, if indicated. Exclusion criteria: the presence of primary hematological disorders, infection, atrial fibrillation, hyperthyroidism, and acute non-cardiac thrombosis (previous embolism and previous oral anticoagulant use). The research was approved by Ethical Committee of Faculty of Medicine, Public Health and Nursing Universitas Gadjah Mada.

An MPV was measured from peripheral blood by automated machine in central hospital laboratory as a routine procedure. Subsequent coronary angiography and $\mathrm{PCl}$ (if indicated) was performed using standardized method in the cath labs of our hospital. A Syntax score was determined to reflect the atherosclerotic severity. A Syntax score data was generated from interpretation of the results of catheterization by Interventional Cardiologists. Statistics analysis was used to assess whether an MPV as a predictor of severity of atherosclerotic based on Syntax score, by univariate and multivariate analysis. $A$ $p$ value $<0.05$ was set as statistics significance.

\section{RESULT}

The basic characteristics of the study consisted of 62 men (72\%) and 24 women $(28 \%)$ subjects. The mean age of subjects was $62.4 \pm 9.1$ years old. Subjects with BMI $\geq 25 \mathrm{~kg} / \mathrm{m}^{2}$ were as many as 35 (41\%), mean total cholesterol was $177.1 \pm 51$ (mg /dl), mean LDL level in the study was 118.6 \pm 48.4 $(\mathrm{mg} / \mathrm{dl})$ and the median HDL level in this study was $39 \mathrm{mg} / \mathrm{dl}$. The HDL $<40 \mathrm{mg} / \mathrm{dl}$ had low risk factors for CHD incidence, women with HDL levels > $45 \mathrm{mg} / \mathrm{dl}$ and men $>40 \mathrm{mg} / \mathrm{dl}$ had a low risk of CHD. ${ }^{3}$ In this study the median triglyceride level was $111 \mathrm{mg} / \mathrm{dl}$. Triglyceride levels <150 $\mathrm{mg} / \mathrm{dl}$ had a low risk of the incidence of $\mathrm{CHD}^{3}$ The Syntax score $>22$ were in 43 $(50 \%)$ subjects. Subjects with MPV > 9.9 were 39 (45\%) (Table 1).

The subjects of this study were divided into 2 groups with high MPV value $>9.9 \mathrm{fl}$ and low MPV value $\leq 9.9 \mathrm{fl}$, based on a previous study by Dogan et al. (2012). ${ }^{4}$ The data in demographic characteristics include age and gender, while clinical characteristics include risk factors, body mass index (BMI) and laboratory data on lipid profiles. In this study the majority of men had MPV $\leq 9.9$, whereas in women, $41 \%$ subjects had MPV > 9.9. Statistically there was a significant difference between MPV > 9.9 and MPV $\leq 9.9$ with respect to gender difference with a $p$ value of 0.01 . The 
mean age was tended to be higher in the subjects with MPV > 9.9, i.e. 64.3 years old as compared to the MPV $\leq 9.9$ with a mean age of 60.9 (Table 2).

Table 1. The characteristics in NSTEMI patients enrolled as subjects

\begin{tabular}{|c|c|}
\hline Variables & Frequency \\
\hline \multicolumn{2}{|l|}{ Gender, n (\%) } \\
\hline Men & $62(72)$ \\
\hline Women & $24(28)$ \\
\hline Age, mean $\pm S D$ & $62.4 \pm 9.1$ \\
\hline Hypertension, n (\%) & $62(72)$ \\
\hline Diabetes mellitus, $\mathrm{n}(\%)$ & $35(41)$ \\
\hline Dyslipidemia, n (\%) & $25(29)$ \\
\hline Smoker, n (\%) & $45(52)$ \\
\hline Family History, $\mathrm{n}(\%)$ & $5(6)$ \\
\hline Body mass index $\geq 25, \mathrm{n}(\%)$ & $35(41)$ \\
\hline Total cholesterol (mg/dL), mean $\pm S D$ & $177.1 \pm 51.0$ \\
\hline LDL cholesterol (mg/dL), mean \pm SD & $118.7 \pm 48.4$ \\
\hline HDL cholesterol (mg/dL), median & $40.4(23-82)$ \\
\hline Triglycerides $(\mathrm{mg} / \mathrm{dL})$, median & $111.0(17-702)$ \\
\hline \multicolumn{2}{|l|}{ Syntax Score, n (\%) } \\
\hline$>22$ & $43(50)$ \\
\hline$\leq 22$ & $43(50)$ \\
\hline \multicolumn{2}{|l|}{ MPV, $\mathrm{n}(\%)$} \\
\hline$>9.9$ & $39(45)$ \\
\hline$\leq 9.9$ & $47(55)$ \\
\hline
\end{tabular}

Table 2. Analysis of several variables (counfounding factor) that affect MPV value in NSTEMI patients

\begin{tabular}{|c|c|c|c|}
\hline Variables & $\begin{array}{c}\text { MPV }>9.9 \\
(\mathrm{n}=39)\end{array}$ & $\begin{array}{c}\text { MPV } \leq 9.9 \\
(\mathrm{n}=47)\end{array}$ & $p$ value \\
\hline Gender, n (\%) & & & 0.01 \\
\hline Men & $23(59)$ & $39(83)$ & \\
\hline Women & $16(41)$ & $8(17)$ & \\
\hline Age, mean $\pm S D$ & $64.3 \pm 8.8$ & $60.9 \pm 9.3$ & 0.09 \\
\hline Hypertension, n (\%) & $27(69)$ & $35(75)$ & 0.59 \\
\hline Diabetes mellitus, $\mathrm{n}(\%)$ & $19(49)$ & $16(34)$ & 0.17 \\
\hline Dyslipidemia, n (\%) & $11(28)$ & $10(21)$ & 0.46 \\
\hline Smoker, n (\%) & $23(59)$ & $22(47)$ & 0.14 \\
\hline Family History, $\mathrm{n}(\%)$ & $1(3)$ & $4(8)$ & 0.26 \\
\hline Body mass index $\geq 25, \mathrm{n}(\%)$ & $14(36)$ & $21(45)$ & 0.40 \\
\hline Total cholesterol (mg/dL), mean $\pm \mathrm{SD}^{*}$ & $178.5 \pm 53.8$ & $168.5 \pm 60.1$ & 0.43 \\
\hline LDL cholesterol (mg/dL), mean $\pm \mathrm{SD}^{*}$ & $119.0 \pm 53.9$ & $118.0 \pm 44.5$ & 0.95 \\
\hline HDL cholesterol (mg/dL), median** & $39(23-71)$ & $41(26-122)$ & 0.64 \\
\hline Triglycerides (mg/dL), median** & $109(54-702)$ & $108(64-393)$ & 0.26 \\
\hline Syntax Score, n (\%) & & & 0.50 \\
\hline$>22$ & $18(46)$ & $25(3)$ & \\
\hline$\leq 22$ & $21(54)$ & $22(47)$ & \\
\hline
\end{tabular}


The subjects with Syntax score > 22 were mostly men (72\%) as compared to women $(28 \%)$. In this study, there were more men subjects with high Syntax compared to women. This is in line with the research conducted by Gunaydin et al. (2016). ${ }^{5}$ In the univariate analysis, it was found risk factors for family history and HDL levels showed significant differences. Previous studies revealed that low HDL was caused by increased proliferation of megakaryocyte progenitors and increased production of immature platelets in the bone marrow, thus the relationship between high MPV and low HDL could reflect the presence of an atherogenic and significant CHD. ${ }^{1}$ In research by Gunaydin et al. (2016), it was found that HDL and family history had a significant implication for the incidence of high Syntax scores. ${ }^{5}$ This is consistent with our study with significant association in family history and in HDL level for higher Syntax score (Table 3).

The MPV >9.9 prevalence ratio was 1.15 times for the higher Syntax score (Syntax >22), with no statistical significant $p$ value $(p=0.5)$ (Table 4). Therefore, in this study, which involved NSTEMI subjects undergoing coronary angiography, higher MPV did not have increased risk to the incidence of higher Syntax scores. De Luca et al. (2009) examined MPV in 1411 patients undergoing coronary angiography and showed that MPV was not associated with CAD severity. ${ }^{6}$ In the study conducted by Seyis et al. (2017) also showed no association between MPV and lesion severity based on Syntax score. ${ }^{7}$

Multivariate analysis was carried out on variables that could potentially be confounding factors with $p<0.25$ in the univariate analysis. Multivariate analysis in this study used logistic regression and included smoking, diabetes mellitus, age, family history and HDL variables.
Based on multivariate analysis,
only smoker was independently associated with higher Syntax score (OR $2.531,95 \% \mathrm{Cl} 1.012-6.328, \mathrm{p}=0.047$ ) (Table 5). This is in accordance with research by Huxlley and Woodward (2011) which proved that people who smoke have a greater risk of suffering from coronary heart disease. ${ }^{8}$

\section{DISCUSSION}

It is known that age is one of the risk factors for coronary heart disease where as the age increase, the higher the risk of coronary heart disease. In this study with the mean age of patients was $62.4 \pm 9.1$ years old. The older the age, the bigger the plaque that sticks to the wall and causes the disruption of blood flow through it. Age factors have been shown to be associated with death from coronary heart disease. ${ }^{9}$

Patients with hypertension as risk factor in this study were found in 62 $(72 \%)$ subjects. A study found that half of of coronary heart disease in developing countries occurred due to hypertension. This shows that hypertension is one of the main risk factors for coronary heart disease. While the incidence of hypertension in Indonesia according to WHO amounted to $42.7 \%$ in men and $39.2 \%$ in women. ${ }^{9}$ In this study, subjects who had diabetes mellitus amounted to 35 people $(41 \%)$ and the number of subjects who had dyslipidemia was 25 people (29\%). Smoking is a high risk factor for men and the number of subjects who smoked was 45 people $(52 \%)$, because the dominant risk factors for smoking in men, 4 and men were more susceptible to psychosocial stress than women. ${ }^{10}$

Subjects with a family history of cardiac disease were found in 5 (5.8\%) subjects. Family history of heart disease is a risk factor for coronary heart disease. 
Table 3. Analysis of several variables (counfounding factor) that influence the Syntax score in NSTEMI patients

\begin{tabular}{|c|c|c|c|}
\hline Variables & $\begin{array}{c}\text { Syntax }>22 \\
n=43\end{array}$ & $\begin{array}{c}\text { Syntax } \leq 22 \\
n=43\end{array}$ & $p$ value \\
\hline Gender, n (\%) & & & 0.01 \\
\hline Men & $31(72)$ & $31(72)$ & \\
\hline Women & $12(28)$ & $12(28)$ & \\
\hline Age, mean $\pm S D$ & $63.6 \pm 9.2$ & $61.3 \pm 9.0$ & 0.23 \\
\hline Hypertension, n (\%) & $33(77)$ & $29(67)$ & 0.33 \\
\hline Diabetes mellitus, n (\%) & 21(49) & $14(33)$ & 0.12 \\
\hline Dyslipidemia, n (\%) & $12(28)$ & $9(21)$ & 0.45 \\
\hline Smoker, n (\%) & $18(42)$ & $27(63)$ & 0.05 \\
\hline Family History, n(\%) & $0(0)$ & $5(12)$ & 0.02 \\
\hline Body mass index $\geq 25, n(\%)$ & 19(44) & 16(37) & 0.50 \\
\hline Total cholesterol (mg/dL), mean $\pm S^{*}$ & $181 \pm 51$ & $173 \pm 52$ & 0.43 \\
\hline LDL cholesterol (mg/dL), mean $\pm \mathrm{SD}^{*}$ & $119 \pm 49$ & $118 \pm 49$ & 0.95 \\
\hline HDL cholesterol (mg/dL), median** & $43(26-82)$ & $37(23-67)$ & 0.64 \\
\hline Triglycerides (mg/dL), median** & $108(54-459)$ & 132(17-702) & 0.26 \\
\hline MPV & & & 0.50 \\
\hline MPV high (>9.9) & $21(49)$ & $18(42)$ & \\
\hline MPV low $(\leq 9.9)$ & 22(51) & $25(58)$ & \\
\hline
\end{tabular}

Table 4. Prevalence ratio of MPV value to SYNTAX score in patients with NSTEMI

\begin{tabular}{llllll}
\hline & Syntax $>\mathbf{2 2}$ & Syntax $\leq \mathbf{2 2}$ & PR & P value & 95\% Cl \\
\hline MPV $>$ 9.9, $\mathbf{n}(\%)$ & $21(49)$ & $18(42)$ & 1.15 & 0.5 & $0.755-1.753$ \\
MPV $\leq 9.9, \mathbf{n}(\%)$ & $22(51)$ & $25(58)$ & & & \\
\hline
\end{tabular}

The risk increases if the father or brother is diagnosed with CHD before the age of 55 years, or if the mother or sister is diagnosed with CHD before age 65 years. A positive family history of coronary heart disease increases the likelihood of premature atherosclerosis. ${ }^{3}$ According to the World Heart Federation, the tobacco contained in cigarettes can cause a decrease in oxygen levels that are flowed by blood and cause blood to clot easily. Blood clots that form in these arteries can cause coronary heart disease and also strokes and sudden death. Other literature from the Heart
Foundation states that tobacco has a pathophysiologics effect on the heart, blood clotting system, and lipoprotein metabolism. Smoking increases coronary plaque formation and promotes coronary thrombosis. Smoking can also increase oxygen demand by the heart muscle and reduce the blood's ability to carry oxygen. $^{9}$

In this study, there were more men subjects with high SYNTAX compared to women. This is in line with the research conducted by Gunaydin et al. (2016). ${ }^{5}$ In the univariate analysis found risk factors for family history and 
HDL levels showed significant differences. Previous studies revealed that low HDL was caused by increased proliferation of megakaryocyte progenitors and increased production of immature platelets in the bone marrow, thus the relationship between high MPV and low HDL could reflect the presence of an atherogenic and significant $\mathrm{CHD}{ }^{1}$ Other study showed that HDL and family history had a significant $p$ value for the incidence of high SYNTAX. ${ }^{5}$ Hindieh et al. (2014) showed that a family history of coronary heart disease is associated with the severity of coronary anatomics lesions and needs to be given earlier and more aggressive attention in the management of CAD. ${ }^{11}$

Study conducted by Murat et al. (2013) show for the first time a positive relationship between MPV and the severity of CAD with Gensini scores and SYNTAX scores. $^{12}$ In our study, significant values were found in smoking risk factors. Mean platelet volume has been demonstrated as an indicator of platelet activation, and plays an important role in the pathophysiology of Atherosclerotic disease. The results of previous studies indicate that an increase in MPV is associated with cardiovascular disease. Some reports have shown that MPV is closely related to risk factors for heart disease. The increasing MPV has been recognized as an independent risk factor for myocardial infarction and adverse cardiovascular events such as recurrent ischemia or death. Several studies have shown an association between MPV and CAD, stable angina pectoris, unstable angina pectoris, and acute myocardial infarction and also reported that MPV is associated with impaired myocardial perfusion and restenosis after primary coronary intervention. $^{12}$

Murat et al. (2013) showed that platelet size can play a role in CAD severity. ${ }^{12}$ Although the pathogenesis of the relationship between increased MPV and the severity of CAD is not fully understood, several mechanisms may be involved. The association between high MPV and the severity of CAD can be explained by an increase in the number of leukocytes, platelets and platelet aggregation in the coronary arterioles that cause microvascular injury. Chemotactic and mitogenic factors and CD40 ligands, expressed by platelet activation, can contribute to the level and severity of coronary atherosclerosis. ${ }^{12}$ The level and severity of coronary heart disease may also cause an increase in platelet production with high MPV, and these larger platelets can join to form plaque and contribute to the initiation of ACS. $^{12}$

Table 5. Multivariates Analyis confounding factor MPV that influence the SYNTAX score

\begin{tabular}{lccc}
\hline \multicolumn{1}{c}{ Variables } & OR & IC 95\% & P \\
\hline MPV High & 1,049 & $0,409-2,688$ & 0,92 \\
Smoker & 2,531 & $1,012-6,328$ & $\mathbf{0 , 0 4 7}$ \\
Diabetes & 1,870 & $0,683-5,116$ & 0,223 \\
Family History & 0,000 & 0,000 & 0,99 \\
Age 63 years & 0,744 & $0,278-1,997$ & 0,56 \\
HDL & 0,708 & $0,111-4,504$ & 0,714 \\
\hline
\end{tabular}

OR : Odds Ratio, IC : Interval Confidence, $\mathrm{p}$ : kadar kemaknaan 
In this study, patients with time to complain of chest pain ranged from 1 hour to more than 1 hour or even several days, and had received a double platelet loading dose (DAPT) thus allows for various MPV results to occur. Aspirin works by blocking the thromboxane activation pathway and thus can affect changes in platelet shape and can affect the magnitude of MPV. ${ }^{13}$ Research shows that chest pain 1 hour after the attack has been found to increase MPV. Furthermore, higher MPV has been detected in the first hour of disability from plaque and since the incidence of infarction. ${ }^{14} \mathrm{~A}$ study conducted by Khode et al. (2012) reported a 6-hour increase in MPV since chest pain attacks, ${ }^{15}$ and Chu et al. (2011) reported an increase in MPV at 4 hours from the onset of chest pain. ${ }^{16}$ Tavil et al. (2007) measured MPV in 205 patients with metabolic syndrome who underwent coronary angiography and did not see any difference in MPV values between patients with or without significant CAD (patients with > 50\% atherosclerosis). ${ }^{17}$ Ihara et al. (2006) reported that MPV is lower in positive angiographic patients than negative angiography patients. ${ }^{18}$

\section{Limitations}

This study was conducted cross-sectional by taking secondary data from medical records, it would be better if done in a cohort and also control the sampling time and length of the examination process as well as the material used for blood storage.

\section{CONCLUSION}

A high MPV value does not have a high prevalence ratio to the incidence of severe atherosclerosis by coronary angiography in NSTEMI patients.

\section{ACKNOWLEDGEMENT}

Authors acknowledge Dr. Arif Wibisono and Dr. Aditya Damarkusuma for help and support in completing this research.

\section{REFERENCES}

1. Taskesen T., Sekhon H., Wroblewski I., Goldfarb M., Ahmad M.B., Nguyen Q.T., et al. 2017. Usefulness of mean platelet volume to predict significant coronary artery disease in patients with non ST-elevation acute coronary syndromes. Am J Cardiol, 119:192-196.

2. Mirzaie A.Z., Abolhasani M., Ahmadinejad B., Panahi M. 2012. Platelet count and MPV, routinely measured but ignored parameters used in conjunction with the diagnosis of acute coronary syndrome: single study center in Iranian population. Med J Islam Repub Iran, 26:17-21.

3. Piepoli M.F., Hoes A.W., Agewall S., Albus C., Catapano C.B.A.L., Cooney M.T., et al. 2016. European Guidelines on cardiovascular disease prevention in clinical practice: The Sixth Joint Task Force of the European Society of Cardiology and Other Societies on Cardiovascular Disease Prevention in Clinical Practice. Eur Heart J, 37:2315-2381.

4. Dogan A., Aksoy F., Icli A., Arslan A., Varol E., Uysal B.A., et al. 2012. Mean platelet volume is associated with culprit lesion severity and cardiac events in acute coronary syndromes without ST elevation Blood Coagulation and Fibrinolysis, Blood Coagul Fibrinolysis, 23:324330.

5. Gunaydın Z.Y., Karagoz A., Bektas O., Kaya A., Kırıs T., Erdogan G., et 
al. 2016. Comparison of the Framingham risk and SCORE models in predicting the presence and severity of coronary artery disease considering SYNTAX score. Anatol J Cardiol, 16:412-418.

6. De Luca G., Santagostinoa M., Seccoa G.G., Cassetti E., Giuliani L., Franchi E., et al. 2009. Mean platelet volume and the extent of coronary artery disease: Results from a large prospective study. Atherosclerosis, 206:292-297.

7. Seyis S., Gunay S., Rencuzoglu I. 2017. Relationship between platelet to lymphocyte ratio and coronary angiography timing in patients with NSTEMI. Biomed Res, 28:89458950.

8. Huxley R.R., Woodward M. 2011. Cigarette smoking as a risk factor for coronary heart disease in women compared with men: a systematic review and meta-analysis of prospective cohort studies. Lancet, 378:1297-1305.

9. Ghani L., Susilawati M.D., Novriani H. 2016. Faktor risiko dominan penyakit jantung koroner di Indonesia. Buletin Penelitian Kesehatan, 44:153-164.

10. Street M. 2000. Why do men get more heart disease than women? An

international perspective. J Am Coll Health, 48:291-294.

11. Hindieh W., Pilote L., Cheema A., Labos C., Dufresne L., Engert J.,et al. 2016. Association between family history and severity of coronary artery disease in patients with premature acute coronary syndromes. Can J Cardiol, 36:128692.

12. Murat S.N., Duran M., Kalay N.,
Gunebakmaz O., Akpek M., Doger C., et al. 2013. Relation between mean platelet volume and severity of atherosclerosis in patients with acute coronary syndromes. Angiology, 64:131-136.

13. Yilmaz M.B., Cihan G., Guray Y., Guray U., Kisacik H.L., Sasmaz $\mathrm{H}$., et al. 2008. Role of mean platelet volume in triagging acute coronary syndromes, 26:49-54.

14. Gasparyan A.Y., Ayvazyan L., Mikhailidis D.P., Kitas G.D. 2011. Mean platelet volume. A link between thrombosis and inflammation?. Curr Pharm Design, 17:47-58.

15. Khode V., Sindhur J., Kanbur D., Ruikar K., Nallulwar S. 2012. Mean platelet volume and other platelet volume indices in patients with stable coronary artery disease and acute myocardial infarction: A case control study. J Cardiovasc Dis Res, 3:272275.

16. Chu H., Chen W.L., Huang C.C., Chang H.Y., Kuo H.Y., Gau CM., et al. 2011. Diagnostic performance of mean platelet volume for patients with acute coronary syndrome visiting an emergency department with acute chest pain: the Chinese scenario. Emerg Med J, 28:569-574.

17. Tavil Y., Sen N., Yazici H.U., Hizal F., Abaci A., Cengel A. 2007. Mean platelet volume in patients with metabolic syndrome and its relationship with coronary artery disease. Thromb Res, 120:245-250.

18. Ihara A., Kawamoto T., Matsumoto K. 2006. Relationship between platelet indexes and coronary angiographic findings in patients with ischemic heart disease. Pathophysiol Haemost Thromb, 35:376-379. 